\title{
Information and Communication Technologies (ICTs) in Secondary Educational Institutions in the uMhlathuze Municipality, South Africa: an insight into their utilisation, impact, and the challenges faced
}

\author{
Janneke Mostert ${ }^{\prime}$ and Mduduzi Nthetha ${ }^{2}$ \\ Department of Library and Information Science, University of Zululand, \\ Private Bag XI00I, KwaDlangezwa. 3886. South Africa \\ jmostert@pan.uzulu.ac.za,mduduzi_ntetha@yahoo.co.uk
}

Received: $/ 2^{\text {th }}$ June 2007
Accepted: $15^{\text {th }}$ October 2007

In order to cope with the demands that stem from our modern day, information-based global economy, present day school leavers need to be equipped with skills that would allow them to meaningully contribute towards their respective working and social environments. The ability to utilise ICTs effectively is of paramount importance, as they enable individuals to continuously adapt to change and to develop the skills associated with life long learning. Recognising this, the South African government has pledged that all school children will be able to utilise ICTs by 20I3. This study, which forms part of a more comprehensive study amongst both learners and staff in secondary schools in the uMhlatuze municipality, reports on ICTs and their utilisation, impact, and the challenges faced amongst learners from secondary schools in the Umhlatuze municipality. The findings reveal that while various ICTs are available in most of the schools, accessibility is still a problem. As educational tools, their impact is still negligible, and numerous challenges were identified. Yet despite these drawbacks, the learners expressed an eagerness and willingness to enhance their ICT skills and utilise the tools for their own empowerment.

Key Words: Information and Communication Technologies; ICTs; Secondary Education; uMhlathuze Municipality; South Africa

\section{Introduction}

Many countries have invested in information and communications technologies (ICTs) as a way to pursue their educational goals. ICTs are generally regarded as technologies that support an individual's ability to manage and communicate information electronically, and include hardware such as computers, printers, scanners, video recorders, television, radio, and digital cameras; as well as the software and systems needed for communication, such as the Internet and e-mail (Bialobrezeska \& Cohen, 2003). Although video recorders, television, radio and digital cameras are used less than computers and the Internet as teaching and learning media, they are still utilised in many schools as alternative teaching tools, especially in areas where Internet access is problematic (such as in rural areas with poor telecommunications infrastructure). However, in most schools, computers and the Internet emerge as the leading ICT tools utilised during the learning process, especially within the context of recording, processing, storing, and sharing information (Bialobrezeska \& Cohen, 2003).

De Jager \& Lockman (1999:n.p.) identified four uses of ICTs in the educational environment, namely:

- ICTs as objects, i.e. learning about ICTs mainly through an available course. What is offered depends on the educational level of the students. ICT teaching prepares students for the use of ICTs in education, future occupations, and social life.

- ICTs as an "assisting tool", whereby ICTs are used as tools in writing assignments, collecting data and documentation, and communicating and conducting research, to name a few. The ICTs are operated independently of the subject matter.

- As a medium for teaching and learning, whereby teachers can teach, and learners, learn using ICTs. This can take many forms, such as drill and practice exercises, simulations, and educational networks.

- As a tool for organisation and management in schools.

Realising the benefits of new technologies, especially those that could potentially revolutionise the way education is practiced, presents its own challenges. These challenges/hindrances - as ever more pronounced in developing countries include the following:

- Conservative attitudes and behaviour, such as the text- and blackboard-bound teaching of the [teaching] staff, or the taboos of the learners' parents concerning the utilisation of technology in the teaching and learning process (Rusten, n.d.). The integration of computers in the classroom is still a relatively new concept. With the new trend in the educational field geared towards problem-based or investigative learning, it is required of the teacher to relinquish

I. Janneke Mostert, PhD, is a Senior Lecturer in the Department of Library and Information Science, University of Zululand, South Africa.

2. Mduduzi Ntetha is a masters student in the Department of Library and Information Science, University of Zululand, South Africa 
some control over the learning process and assume the role of "facilitator" as opposed to "provider" (Isaac et al., 2004:n.p.).

- A lack of sufficient coherent government policies regulating the training of educators in the utilisation of ICTs within the educational environment.

- A shortage of funding needed to implement existing policies. Although many countries are aware of ICTs as important educational tools, there are just too many other obligations that first have to be met before significant investment is made in a field this new.

- A shortage of quality training staff to train teachers. Skilled facilitators need to be available to act as trainers for both teachers already in the field, and those in training. Furthermore, the training material needs to be developed in order to suit the needs of those who are to utilise it within the school environment.

- The lack of access to ICT facilities at school. To use ICTs, especially computers and the Internet, electricity and telephone lines are imperative. ICT access would allow both the teacher and the learner to develop the skills necessary to integrate ICTs into the learning environment, for example to access additional information for lesson preparation or assignments, for communication with colleagues, and so on. (Isaac-Bardien, 2004: n.p.).Unfortunately, access and availability is in many cases highly restricted, as ICTs may only be available to specific staff members, or alternatively may be totally absent (Isaac-Bardien, 2004: n.p.).

- Cost - everything connected to ICTs, ranging from the development of course materials, to teacher training and technical support staff, has a related cost factor. With the perennial lack of funds, it is clear that governments alone cannot support a large scale investment in these technologies, and therefore external support, be it via parents or donors, becomes the only viable option for the schools (Isaac et al., 2004: n.p.). Where schools do have ICTs, they tend not to budget for maintenance, and rather buy new technology or spend their funds on software (Isaac et al., 2004; Isaac-Bardien, 2004: n.p.).

- Lack of infrastructure. Without proper infrastructure, online learning is directly hampered. Infrastructure related aspects that prevent schools from acquiring computers include the absence of electricity, lack of funding, insufficient space, lack of available and trained staff, and poor security (Isaac et al., 2004: n.p.).

A number of studies describe the ICT environment in secondary schools in South Africa (Bialobrezeska \& Cohen 2003; Herselman 2002; Isaacs 2002). Many of these studies investigate the utilisation of ICTs from the educators' viewpoint. No studies could be found providing insights into the utilisation of ICTs from the learner's perspective. As learners are the leaders and workforce of tomorrow, it is important to establish whether they are technologically equipped enough to cope with the demands that society will make of them. Therefore, the study aimed to gain an insight into the availability and use of ICTs by learners in the high schools within the Umhlatuze municipality. The objectives of the study included: to determine the availability of ICTs in the schools and the utilisation thereof by learners; to determine whether and/or how ICTs have influenced information seeking and communication behaviour; to establish the ICT skills that the learners currently possess; and to establish the problems or limitations hampering the effective utilisation of ICTs within the school environment.

\section{ICTs in South African schools}

Since 1994, the educational system in South Africa has undergone major changes, moving away from a system that offered substandard schooling to black South Africans and a high matric failure rate, to a national curriculum, Curriculum 2005 , based on outcomes-based education, which requires the learning process to be an interaction between learner and teacher. Although not specifically referring to the use of ICTs in achieving specific outcomes, Curriculum 2005 makes provision for their utilisation wherever appropriate in achieving an outcome (Holcroft, 2004). In 2004, the Department of Education published the White Paper on e-Education, in which they committed themselves to developing ICT capabilities amongst all school children from Grade I-I 2 by 2013 (Department of Education, 2004). The main goal of this policy is to enable South African learners to "confidently and creatively develop the skills and knowledge they need both to achieve personal and economic goals and to participate effectively as a member of the global community" (Department of Education, 2004:18).

Attaining these lofty ideals may prove daunting. Both Matume in Holcroft (2004) and the survey conducted by the South African Institute of Race Relations in 2002 (Bialobrezeska \& Cohen, 2003) painted a bleak picture of the level of infrastructure currently available in schools for ICTs. The 2002 study revealed that less than half of the schools had access to electricity (without which ICT tools can't function). The availability of computers in schools was also minimal, with only $26.5 \%$ having computers for learning and teaching (Department of Education, 2004). Matume in Holcroft (2004) further revealed that only $59 \%$ had access to telephone lines. Taking into account the three prerequisites for telecommunications connectivity, namely electricity, exchange telephone lines, and two or more computers; only 15\% of the schools complied. A study done by Herselman (2002) on resource deprived schools in the Port Elizabeth area showed that $75 \%$

SA JnI Libs \& Info Sci 2008, 74(I) 
had access to telephones (both landline and wireless), and $90 \%$ had electricity, but only $20 \%$ had computers. Internet access was only available to $17 \%$ of the schools.

Availability and access to computers also varied amongst the different provinces, with some being well equipped, and others having virtually no equipment. Table I illustrates these disparities.

Table I Draft white paper on education: transforming education and learning through information and communication technologies (ICTs).

\begin{tabular}{|l|l|l|}
\hline Provinces & Schools with computers & Schools with computers for teaching and learning \\
\hline Eastern Cape & $8.8 \%$ & $4.5 \%$ \\
\hline Free State & $25.6 \%$ & $12.6 \%$ \\
\hline Gauteng & $88.5 \%$ & $45.4 \%$ \\
\hline KwaZulu-Natal & $16.6 \%$ & $10.4 \%$ \\
\hline Mpumalanga & $22.9 \%$ & $12.4 \%$ \\
\hline Northern Cape & $76.3 \%$ & $43.3 \%$ \\
\hline Limpopo & $13.3 \%$ & $4.9 \%$ \\
\hline North West & $30.5 \%$ & $22.9 \%$ \\
\hline Western Cape & $82.4 \%$ & $56.8 \%$ \\
\hline National & $39.2 \%$ & $26.5 \%$ \\
\hline
\end{tabular}

Government Gazette, 470:26734:12

A study done by the Education Policy Unit of the University of the Western Cape and the International Development Research Centre (2000:n.p.) noted that of the 6000 high schools in the country, 23II had access to at least one computer.

In 2004, the Minister of Education acknowledged the role that ICTs play in improving the quality of education and training, and conceded that to provide these technologies to all schools would require significant investment from all stakeholders (Department of Education, 2004).

Major developments concerning ICTs in education in South Africa

As South Africa possesses relatively well developed technological infrastructure, the introduction of technology into the school curriculum has been a focal point since the early 90 's. According to James (200I), South Africa has done more than any other Sub- Saharan country to establish an educational ICT policy. Since 1995, it has been on the policy agenda of the Department of Education (DoE). In 1996, the Ministry of Education and the Department of Education initiated the Technology-Enhanced Learning Investigation (TELI) in order to establish a clear policy framework for the effective use of technologies in education, which led to a series of policy processes (Holcroft, 2004). This resulted in a Discussion Document which was completed in 1996. The focus of this document was on the development of an enabling infrastructure for the effective use of technologies in education and training. As part of this document, a TELI decisionmaking framework was also developed. The framework emphasised "the appropriateness of technological choice to educational context and need, as a prerequisite to ensuring that scarce resources are used as effectively as possible" (James, 200I:n.p.).

Based on this document, the then Minister of Education, Kader Asmal, appointed a team of experts to develop a framework and set of guidelines for choosing technologies to introduce into the teaching and learning environments. This process was completed in 1998 (James, 200I:n.p). The national ICT Forum was established to guide national ICT strategy.

In 2004, the government published a draft White paper, whose aim was to transform the education environment through the use of ICTs. In this document, e-education is described as more than the development of computer literacy and the skills necessary to operate the various types of ICTs, as it also includes the ability to:

- Apply ICT skills in order to access, analyse, evaluate, integrate, present, and communicate information

- Create knowledge and new information by adapting, applying, designing, inventing, and authoring information

- Function in a knowledge society by using appropriate technology and mastering communication and collaborative skills (Department of Education, 2004:14)

Therefore, ICTs are viewed as resources that can be used to reorganise schooling, and as tools that assist whole-school development. ICTs are therefore:

- Tools for management

- Administrative tools used to increase productivity

- Resources for curriculum integration

- Communication tools

- Collaborative tools for teachers and learners

SA JnI Libs \& Info Sci 2008, 74(I) 
- A learning environment that advances productivity, creativity, communication, collaboration, and engagement (Department of Education 2004:I4).

The use of ICTs in South African schools: case studies

Studies done by Intel amongst rural schools identified the following challenges that need to be addressed in order to reap the full benefits of ICTs in classrooms: lack of access to technology; lack of computer literacy amongst teachers; the absence of a properly developed curriculum for integrating ICTs into subject teaching; and the need for student-centered learning and outcome-driven educational approaches (Intel World Ahead Program: Case studies n.d.). The studies also showed that funds for technology infrastructure, especially in rural schools, are scarce, and that the legacy of apartheid has created huge differences between the provinces in terms of resources, management expertise, educator capacity, and commitment.

In a study done in the Ethekwini municipality in KwaZulu-Natal, Govender and Maharaj (n.d) established that although the teachers were positive about the uses of technology, they all sadly lacked the skills to implement and use it in their classrooms. The study showed that technological proficiency was very low amongst the majority of the respondents, with the lack of skills most pronounced amongst the African teachers and at schools serving mostly the lower and middle income economic sector. Computers were mainly used to teach subjects such as Computer Studies or Comp-Typing, and not for curriculum enhancement or development. This notion is supported by a survey done by the International Development Research Centre (n.d), which pointed out that if computers were used for any other purposes, it was mainly in the arenas of language, mathematics, and natural sciences and technology, for practicing and problem-solving. The survey showed that the use of computers was enhanced when classes were small in size, when parents were able to afford the additional costs, when the use of ICTs was integrated into normal school hours, and by the presence of a dedicated computer teacher.

Isaacs (2002) found that despite having the highest tele-density in Africa, South African schools are ill-equipped with computers, with only a few providing access to the Internet. Isaac's (2002) study showed that the major obstacles to Internet access were:

- Lack of infrastructure in general, and network infrastructure in particular

- High telephone costs and the high cost of Internet access

- Limited expertise, and

- Lack of an enabling policy environment

Huge disparities also exist in terms of how many computers are available in schools, with some only having one computer for the whole school, while others have up to forty. The condition of the computers also ranges from refurbished to top of the range. Access to computers was in most cases limited to Grades II and I 2 only (Isaac 2002).

Lack of electricity does not necessarily need to be a deterrent in using technologies. At Myeka High School in KwaZulu Natal, solar panels and biogas are used to access electricity. Using this power source provided access for both learners and teachers to equipment such as computers, a TV and VCR, an overhead projector, links to the Internet, and a printer (Isaacs 2002; Herselman 2003).

\section{Contextualisation}

The uMhlatuze municipality is situated in the province of KwaZulu-Natal on the East Coast of South Africa, about I70 kilometers north of Durban. Although situated in a rural area, the municipality is currently one of a few major industrial growth points in the country. The municipality comprises an area covering $796 \mathrm{sq}$ kilometers, with a total estimated population of 333860 (uMhlatuze City Annual report 2005/06 2006). The area contains a few major towns, namely Richards Bay, Empangeni, Esikhawini, Ngwelezane, Vulindlela and Nseleni. Schools, both primary and secondary, are mainly situated within the towns, or lie adjacent to them. Nineteen secondary schools are available within the area, and are either private schools, or state-supported schools. 
Table 2 Secondary schools in the uMhlatuze City area

\begin{tabular}{|c|c|c|}
\hline Town & School & Status \\
\hline \multirow[t]{3}{*}{ Richards Bay } & John Ross College & State-supported \\
\hline & Richards Bay Secondary School & State-supported \\
\hline & Richardsbaai Hoërskool & State-supported \\
\hline \multirow[t]{4}{*}{ Empangeni } & Empangeni High school & State-supported \\
\hline & St Catherine's & Private \\
\hline & Old Mill School & Private \\
\hline & Dover & Private \\
\hline \multirow[t]{6}{*}{ Esikhawini township } & Matamzana DubeHigh School & State-supported \\
\hline & Hlamvana High School & State-supported \\
\hline & Khula High School & State-supported \\
\hline & Tisand & State-supported \\
\hline & Mdlamfe High School & State-supported \\
\hline & Dlamvuzo High School & State-supported \\
\hline \multirow[t]{3}{*}{ Vulindlela township } & Dlangezwa High School & State-supported \\
\hline & Qhakaza High School & State-supported \\
\hline & Ongoye high School & State-supported \\
\hline \multirow[t]{2}{*}{ Ngwelezane township } & Khombindlela High School & State-supported \\
\hline & Thanduyise High School & State-supported \\
\hline Nseleni township & Tholokuhle High School & State-supported \\
\hline
\end{tabular}

Although three of the schools are deemed private, two of the schools, namely Dover and Old Mill, are donor-supported schools that also receive state support to enable them to survive. Their facilities are thus not on the same level as what can be expected from private schools. As is the case in the rest of the country, state-supported schools rely on three sources of financing, i.e. state funds, parent fees, and other forms of fundraising; to cover both non-personnel (facilities, equipment and learning materials) and personnel expenses. If taking into account that only $8-10 \%$ of a school budget is allocated to non-personnel expenses, it is highly questionable whether most schools are able to sufficiently meet their ICT needs (Roithmayr, 2002).

\section{Methodology}

This study forms part of a comprehensive study amongst both staff and learners at the secondary schools in the uMhlatuze municipal area completed recently. Only the findings focusing on the learners is reported in this paper. The study outcome focusing on educators will be reported in our next paper. However, reference to their responses will be made in the discussion and conclusion section where applicable. A survey research was used as the study method.. The data-gathering instrument used was a self-administered questionnaire. This instrument was chosen because assessing learners on an individual basis would have been time-consuming and impractical, largely because the study had to be conducted during school hours, the learners were not available during school periods, and breaks were too short to make significant progress. The questionnaire consisted of three sections. Section one aimed to gather personal information from the respondents, Section 2 focused on the accessibility, availability and utilisation of ICTs within the school environment, and Section 3 aimed to determine existing skills and competencies in the utilisation of ICTs, as well as what problems hampered the utilisation of ICTs in schools.

All nineteen secondary schools in the uMhlatuze municipality were targeted, and after making prior appointments with the headmasters, the objectives of the study were explained to them and permission was sought to continue. Their co-operation was solicited, and though it was a very busy time of the year, permission to conduct the study was granted. However, no permission was given to personally distribute and collect the questionnaires, and therefore a contact teacher from each school was appointed to assist the researcher. All further communication was done through this teacher. Non-probability sampling was used, initially targeting $3 \%$ of each school's learners. This ratio was fairly adequate. However as shown in Table 3, this ratio was not always attained because the contact teachers were in most cases not very willing to assist us, and sometimes insisted on only taking what they felt like handing out. Teacher willingness to assist was influenced by factors, such as the upcoming exams and Matric (school leavers) farewell parties, and some indicated that they felt "forced" to assist by their principals, and were therefore not very helpful. Although this proved problematic, 
it was the only way to at least gain some insight into the ICT utilisation of each school. In some cases however, such as St. Catherines (a private Girls school), they were more than willing to assist, and insisted on having more questionnaires.

Teachers were briefed on the aim of the study and the method of questionnaire distribution was explained to them. Non-probability sampling, specifically the haphazard method, was used to select the participating learners as the researchers wanted to prevent the handing out of papers to a specific class. This method was chosen as representativeness of a specific gender or class level was not required (Sarantakos 1997) and it allowed the teacher to hand it out to any learner whom he/she came into contact with.

The questionnaires were delivered and left with the contact teacher for distribution and collection. Returned questionnaires were collected from the teachers after a week. While most of the schools had the questionnaires ready for collection, four schools, namely John Ross College, Qhakaza High School, Khombindlela High School, and the Old Mill School; did not return any of the questionnaires. Follow-up calls and visits to these schools were met with no success. Calls were either not returned or the contact teachers were not available during visits, even though appointments were made. At some of the responding schools, it took more than one visit to collect all the papers.

The timing of the study proved problematic, since it coincided with Matric farewell preparations and parties, as well as exams at some schools. A total of 447 questionnaires were distributed to the learners, and $366(82 \%)$ were returned. The following table illustrates the schools' learners population as well as how many questionnaires were handed out and received from each school.

Table 3 Number of respondents and response rate

\begin{tabular}{|l|l|l|l|}
\hline Schools & Learner total & Handed out & Received back \\
\hline Dlamvuzo High School & 956 & 27 & 27 \\
\hline Dlangezwa High School & 920 & 35 & 32 \\
\hline Dover & 860 & 26 & 12 \\
\hline Empangeni High school & 1266 & 38 & 33 \\
\hline Hlamvana High School & 1151 & 30 & 26 \\
\hline Khula High School & 1385 & 28 & 16 \\
\hline Matamzana DubeHigh School & 1038 & 31 & 31 \\
\hline Mdlamfe High School & 700 & 32 & 30 \\
\hline Ongoye high School & 783 & 23 & 19 \\
\hline Richards Bay Secondary School & 1100 & 40 & 39 \\
\hline Richardsbaai Hoërskool & 812 & 30 & 26 \\
\hline St Catherine's & 128 & 20 & 19 \\
\hline Thanduyise High School & 771 & 24 & 21 \\
\hline Tholokuhle High School & 1200 & 36 & 16 \\
\hline Tisand & 900 & 27 & 19 \\
\hline
\end{tabular}

Data analysis was done using SPSS software. Learners' data was analysed according to the school they attended. This was in order to determine whether schools located in a more rural setting had any influence on the availability and utilisation of ICTs amongst the learners.

\section{Results and discussions}

The results are reported in sections 5.1 to 5.12 and in tables 4 to 15 .

\subsection{Availability of ICTs in the schools}

The schools in the uMhlatuze municipality seem to be relatively well endowed with ICTs. Even schools in the more rural areas have a variety of ICTs available for utilisation. This is in contrast to the findings of Bialobrezeska \& Cohen (2003) and Holcroft (2004), who expounded on the dearth of ICTs in South African schools.

Notably, Dover School, which is a private school catering for mainly previously disadvantaged learners, does not have access to computers and a fax machine, while all the other schools, both state-supported and private, have these facilities. The fact that these facilities are available at the schools is an indication that electricity is also available. This, combined with the availability of telephones at all the schools, means that the basic infrastructure for Internet access is available. Table 3 shows the ICTs available at each school. 
Table 4 Availability of ICT tools and services

\begin{tabular}{|l|l|l|l|l|l|l|l|l|l|l|l|}
\hline Schools & Computers & Internet & E-mail & $\begin{array}{l}\text { Electronic } \\
\text { Databases }\end{array}$ & $\begin{array}{l}\text { DVD/CD- } \\
\text { ROM }\end{array}$ & Fax & Telephone & $\begin{array}{l}\text { Mobile } \\
\text { Phone }\end{array}$ & Television & Radio & Video \\
\hline Dlamvuzo & $\mathrm{X}$ & - & - & - & $\mathrm{X}$ & $\mathrm{X}$ & $\mathrm{X}$ & $\mathrm{X}$ & - & - & $\mathrm{X}$ \\
\hline Dlangezwa & $\mathrm{X}$ & $\mathrm{X}$ & $\mathrm{X}$ & $\mathrm{X}$ & $\mathrm{X}$ & $\mathrm{X}$ & $\mathrm{X}$ & $\mathrm{X}$ & $\mathrm{X}$ & $\mathrm{X}$ & $\mathrm{X}$ \\
\hline Dover & - & - & - & - & - & - & $\mathrm{X}$ & $\mathrm{X}$ & $\mathrm{X}$ & $\mathrm{X}$ & $\mathrm{X}$ \\
\hline Empangeni & $\mathrm{X}$ & $\mathrm{X}$ & $\mathrm{X}$ & $\mathrm{X}$ & $\mathrm{X}$ & $\mathrm{X}$ & $\mathrm{X}$ & $\mathrm{X}$ & $\mathrm{X}$ & $\mathrm{X}$ & - \\
\hline Hlamvana & $\mathrm{X}$ & $\mathrm{X}$ & $\mathrm{X}$ & $\mathrm{X}$ & $\mathrm{X}$ & $\mathrm{X}$ & $\mathrm{X}$ & $\mathrm{X}$ & $\mathrm{X}$ & $\mathrm{X}$ & $\mathrm{X}$ \\
\hline Khula & $\mathrm{X}$ & $\mathrm{X}$ & $\mathrm{X}$ & $\mathrm{X}$ & $\mathrm{X}$ & $\mathrm{X}$ & $\mathrm{X}$ & $\mathrm{X}$ & $\mathrm{X}$ & $\mathrm{X}$ & $\mathrm{X}$ \\
\hline Matamzana & $\mathrm{X}$ & & $\mathrm{X}$ & $\mathrm{X}$ & $\mathrm{X}$ & $\mathrm{X}$ & $\mathrm{X}$ & $\mathrm{X}$ & $\mathrm{X}$ & $\mathrm{X}$ & $\mathrm{X}$ \\
\hline Mdlamfe & $\mathrm{X}$ & $\mathrm{X}$ & $\mathrm{X}$ & $\mathrm{X}$ & - & $\mathrm{X}$ & $\mathrm{X}$ & $\mathrm{X}$ & $\mathrm{X}$ & $\mathrm{X}$ & $\mathrm{X}$ \\
\hline Ongoye & $\mathrm{X}$ & $\mathrm{X}$ & $\mathrm{X}$ & $\mathrm{X}$ & $\mathrm{X}$ & $\mathrm{X}$ & $\mathrm{X}$ & $\mathrm{X}$ & $\mathrm{X}$ & $\mathrm{X}$ & - \\
\hline $\begin{array}{l}\text { Richards Bay } \\
\text { Hoërskool }\end{array}$ & $\mathrm{X}$ & $\mathrm{X}$ & $\mathrm{X}$ & $\mathrm{X}$ & $\mathrm{X}$ & $\mathrm{X}$ & $\mathrm{X}$ & $\mathrm{X}$ & $\mathrm{X}$ & $\mathrm{X}$ & $\mathrm{X}$ \\
\hline $\begin{array}{l}\text { Richards Bay } \\
\text { Sec. School }\end{array}$ & $\mathrm{X}$ & $\mathrm{X}$ & $\mathrm{X}$ & $\mathrm{X}$ & $\mathrm{X}$ & $\mathrm{X}$ & $\mathrm{X}$ & $\mathrm{X}$ & $\mathrm{X}$ & $\mathrm{X}$ & $\mathrm{X}$ \\
\hline St. Catherines & $\mathrm{X}$ & $\mathrm{X}$ & $\mathrm{X}$ & $\mathrm{X}$ & $\mathrm{X}$ & $\mathrm{X}$ & $\mathrm{X}$ & $\mathrm{X}$ & $\mathrm{X}$ & $\mathrm{X}$ & $\mathrm{X}$ \\
\hline Thanduyise & $\mathrm{X}$ & $\mathrm{X}$ & $\mathrm{X}$ & $\mathrm{X}$ & $\mathrm{X}$ & $\mathrm{X}$ & $\mathrm{X}$ & $\mathrm{X}$ & $\mathrm{X}$ & $\mathrm{X}$ & $\mathrm{X}$ \\
\hline Tholokuhle & $\mathrm{X}$ & $\mathrm{X}$ & $\mathrm{X}$ & $\mathrm{X}$ & $\mathrm{X}$ & $\mathrm{X}$ & $\mathrm{X}$ & $\mathrm{X}$ & $\mathrm{X}$ & $\mathrm{X}$ & $\mathrm{X}$ \\
\hline Tisand & $\mathrm{X}$ & $\mathrm{X}$ & $\mathrm{X}$ & $\mathrm{X}$ & $\mathrm{X}$ & $\mathrm{X}$ & $\mathrm{X}$ & $\mathrm{X}$ & $\mathrm{X}$ & $\mathrm{X}$ & $\mathrm{X}$ \\
\hline
\end{tabular}

Table 5 Perceived accessibility of ICTs amongst earners ( $\mathrm{N}=366)$

\begin{tabular}{|c|c|c|c|c|c|c|c|c|c|c|c|c|c|c|c|c|c|c|c|c|c|c|}
\hline \multirow[t]{2}{*}{ Schools } & \multicolumn{2}{|c|}{ Computers } & \multicolumn{2}{|c|}{ Internet } & \multicolumn{2}{|c|}{ E-mail } & \multicolumn{2}{|c|}{\begin{tabular}{|l|} 
Electronic \\
Databases
\end{tabular}} & \multicolumn{2}{|c|}{\begin{tabular}{|l|} 
DVD/ \\
CD-ROM
\end{tabular}} & \multicolumn{2}{|c|}{ Fax } & \multicolumn{2}{|c|}{ Telephone } & \multicolumn{2}{|c|}{$\begin{array}{l}\text { Mobile } \\
\text { Phone }\end{array}$} & \multicolumn{2}{|c|}{ Television } & \multicolumn{2}{|c|}{ Radio } & \multicolumn{2}{|c|}{ Video } \\
\hline & A & $N$ & A & $N$ & A & $\mathrm{N}$ & A & $N$ & A & $N$ & A & $N$ & A & $N$ & A & $N$ & A & $N$ & A & $N$ & A & $\mathrm{N}$ \\
\hline Dlamvuzo & 0 & 27 & 10 & 17 & 2 & 25 & 2 & 25 & 0 & 27 & 0 & 27 & I & 26 & 2 & 25 & 2 & 25 & 2 & 25 & 2 & 25 \\
\hline Dlangezwa & 0 & 32 & 4 & 28 & 9 & 23 & 14 & 18 & 7 & 25 & 12 & 20 & 3 & 29 & 8 & 24 & 7 & 25 & 5 & 27 & 6 & 26 \\
\hline Dover & 0 & 12 & 0 & 12 & 0 & 12 & 2 & 10 & 0 & 12 & 0 & 12 & 7 & 5 & 5 & 7 & 8 & 4 & 3 & 9 & 8 & 4 \\
\hline Empangeni & 0 & 33 & 4 & 29 & 3 & 30 & 4 & 29 & 2 & 31 & 2 & 31 & I & 32 & 6 & 27 & 2 & 31 & 6 & 27 & 0 & 33 \\
\hline Hlamvana & 0 & 26 & 2 & 24 & 0 & 26 & 0 & 26 & 3 & 23 & 0 & 26 & 0 & 26 & 0 & 26 & I & 25 & 2 & 24 & 2 & 24 \\
\hline Khula & 0 & 16 & I & 15 & I & 15 & 2 & 14 & 1 & 15 & 1 & 15 & I & 15 & 1 & 15 & 2 & 14 & 2 & 14 & 1 & 15 \\
\hline Matamzana & 0 & 29 & 17 & 14 & 13 & 18 & 1 & 30 & 10 & 21 & 1 & 30 & 0 & 31 & 14 & 17 & 9 & 22 & 13 & 18 & 6 & 25 \\
\hline Mdlamfe & 0 & 30 & 5 & 25 & 8 & 22 & 0 & 30 & 0 & 30 & 3 & 27 & 0 & 30 & 6 & 24 & 0 & 30 & 1 & 29 & 2 & 28 \\
\hline Ongoye & 0 & 17 & 5 & 14 & 5 & 14 & 3 & 16 & 4 & 15 & 2 & 17 & 1 & 18 & 2 & 17 & 3 & 16 & 2 & 17 & 0 & 19 \\
\hline RBH & 0 & 26 & 0 & 26 & 0 & 26 & 1 & 25 & 1 & 25 & 0 & 26 & 0 & 26 & 0 & 26 & 0 & 26 & 0 & 26 & 10 & 16 \\
\hline RBS & 0 & 39 & 0 & 39 & 0 & 39 & 0 & 39 & 0 & 39 & 0 & 39 & 0 & 39 & 0 & 39 & 0 & 39 & 0 & 39 & 27 & 12 \\
\hline St. Cath & 0 & 19 & 13 & 6 & 13 & 6 & 3 & 16 & 3 & 16 & 0 & 19 & 5 & 14 & 8 & 11 & 10 & 9 & 7 & 12 & 9 & 10 \\
\hline \begin{tabular}{|l} 
Thanduyise \\
\end{tabular} & 0 & 21 & 3 & 16 & 4 & 17 & 0 & 21 & 1 & 20 & 2 & 19 & 4 & 17 & 1 & 20 & 4 & 17 & 3 & 18 & 2 & 19 \\
\hline Tholokuhle & 0 & 16 & 8 & 8 & 0 & 16 & 2 & 14 & $\partial^{2}$ & 13 & 4 & 12 & 13 & 3 & 4 & 12 & 3 & 13 & 4 & 12 & 12 & 4 \\
\hline Tisand & $D^{\circ}$ & 16 & 10 & 9 & 8 & 11 & 5 & 14 & D & 10 & 7 & 12 & I & 18 & 8 & 11 & 8 & 11 & 9 & 10 & 0 & 19 \\
\hline Total & 3 & 363 & 84 & 282 & 66 & 300 & 39 & 327 & 44 & 322 & 34 & 332 & 37 & 329 & 65 & 301 & 59 & \begin{tabular}{|l}
307 \\
\end{tabular} & 59 & \begin{tabular}{|l|}
307 \\
\end{tabular} & 87 & 279 \\
\hline
\end{tabular}

\section{Legend}

$A=$ Accessible

$\mathrm{N}=$ Not accessible

\section{Abbreviations}

RBH: Richardsbaai Hoërskool

RBS: Richards Bay Secondary

St. Cath: St. Catherines 


\subsection{Accessibility of ICTs}

In order to be utilised, ICTs need to be both available and accessible. From the results, it is clear that even if ICTs are available on a school's premises, learners are not necessarily given access to these tools. This is clearly demonstrated by how computers are available in all the schools except Dover, yet only 3 of Tisand's learners indicated that they have access to the technolgy in their school. In terms of access to computer-related software and programmes, only a few learners indicated that they have access. This could be attributed to the fact that learners take computer studies as a subject at school and are thus taught how to use them, which are in line with the findings of Govender and Maharaj (n.d.) and the International Development Research Centre (n.d). An anomaly is Dlamvuzo High School, where the learners indicated that Internet, e-mail, and electronic databases are not available, yet are indicated as accessible. The suggestion here is that these facilities are available at home. Table 5 shows the results in terms of the accessibility of ICTs as perceived by learners.

ICTs normally associated with administrative offices, such as faxes and telephones, were all available at the schools, although not deemed accessible by most of the respondents. This indicates that access is restricted to administrative staff. Therefore the facilities are not available to learners, as is the case in most schools in South Africa (Isaac-Bardien 2004). The main study confirmed this trend as the majority of teachers indicated that ICTs were at their disposal to utilise (Nthetha 2006). Mobile phones, which were perceived by the researcher to be common amongst learners, seem to be a lot less accessible than expected. Perhaps this is an indication of the strict restrictions on the use of mobile phones within the school environment.

ICTs such as the radio, television and video, which have traditionally been used to augment curriculum content, are still available in all the schools. However, availability does not necessarily translate into accessibility, as is shown by the results in the table. The fact that some learners indicated that the ICTs are accessible could possibly be because they are more senior and have therefore been entrusted with the use of these facilities.

Table 6 Purpose for using ICT tools and services

\begin{tabular}{|c|c|c|c|c|c|c|c|}
\hline Respondents & $\begin{array}{l}\text { Communication } \\
\text { with DoE }\end{array}$ & $\begin{array}{l}\text { Communication } \\
\text { with others in the } \\
\text { school }\end{array}$ & $\begin{array}{l}\text { Communication } \\
\text { with friends and } \\
\text { relatives }\end{array}$ & $\begin{array}{l}\text { Collaboration } \\
\text { with colleagues } \\
\text { world wide }\end{array}$ & $\begin{array}{l}\text { Dissemination } \\
\text { of information }\end{array}$ & $\begin{array}{l}\text { Access } \\
\text { information } \\
\text { for learning } \\
\text { purposes }\end{array}$ & \begin{tabular}{|l} 
Doing \\
assignments
\end{tabular} \\
\hline Dlamvuzo & 7 & 7 & 1 & 0 & 2 & 1 & I \\
\hline Dlangezwa & 6 & 0 & 0 & 0 & 0 & 0 & 0 \\
\hline Dover & 9 & 2 & 0 & I & 0 & 0 & 0 \\
\hline Empangeni & 7 & I & 0 & 0 & I & 4 & 4 \\
\hline Hlamvana & 4 & 15 & 1 & 2 & 2 & 0 & 0 \\
\hline Khula & 6 & 2 & 2 & I & I & 2 & 2 \\
\hline Matamzana & 9 & 15 & 2 & 1 & I & 0 & 0 \\
\hline Mdlamfe & 28 & 1 & 0 & 0 & 0 & 0 & 0 \\
\hline Ongoye & 2 & 6 & 1 & 1 & 1 & 0 & 0 \\
\hline $\mathrm{RBH}$ & 13 & 6 & 1 & 0 & 0 & 0 & 0 \\
\hline RBS & 5 & 2 & 27 & 0 & 0 & 0 & 0 \\
\hline St. Cath & 3 & 7 & 0 & 0 & I & I & I \\
\hline Thanduyise & 2 & 0 & 0 & 0 & 0 & 0 & 0 \\
\hline Tholokuhle & 3 & 3 & 0 & 0 & 0 & I & I \\
\hline Tisand & 1 & 4 & 1 & 0 & 2 & 3 & 3 \\
\hline Total & 105 & 71 & 36 & 6 & 11 & 12 & 12 \\
\hline
\end{tabular}

\subsection{Reasons for using ICT tools and services}

It was expected that ICTs which can potentially enhance and enrich the school curriculum would be utilised by those who have access to them. Interestingly, ICTs are mainly used to communicate, and not to seek or retrieve information. The same trend was found amongst the teachers (Nthetha 2006). At a school like Mdlamfe High, for example, 28 (93\%) of the respondents indicated that they used ICTs to communicate with the Department of Education. The reasons for this communication would be interesting to explore, as learners should not normally find such communication necessary. What is disturbing is the virtual exclusion of ICTs for obtaining information for school assignments, as only 12 respondents from all the schools indicated that they use ICTs for this purpose. As libraries are non-existent at most of the schools, it is worth exploring whether assignments are part of the school assessment programme, or alternatively, which sources 
learners use to obtain information for assignments. The fact that most respondents (354) indicated that they do not use ICTs for learning purposes, leads to the assumption that learning is mostly done from class notes and textbooks. Table 6 provides the responses to why ICTs are used by learners.

\subsection{Acquisition of skills to operate computers}

To operate computers, training is needed. At this point we wanted to determine how the learners acquired the skills necessary to operate the computer. Most $(174 ; 47 \%)$ of the respondents appear to be self-taught, which corresponds with the notion that modern young people have the ability to navigate technology on their own, albeit through trial and error. Very few students seem to have learnt their skills at school, which could possibly mean that skills are only taught to those taking Computer Studies as a school subject. Notably, 13 (4\%) respondents indicated that they received training abroad. Perhaps these learners, at some stage, immigrated with their parents or coming from other countries. The sizeable number $(104 ; 28 \%)$ who did not respond to this question, are an indication of the shortage of skills amongst the learners. Visibly, if the government is indeed serious about all school children being ICT literate by 20I3, much work needs to be done. Table 7 illustrates how the learners acquire their skills.

Table 7 How learners obtained skills to use computers $(N=366)$

\begin{tabular}{|l|l|l|l|l|l|l|}
\hline School & Self study & $\begin{array}{l}\text { From fellow } \\
\text { learners }\end{array}$ & $\begin{array}{l}\text { In-house } \\
\text { course, e.g. } \\
\text { Damelin }\end{array}$ & Training abroad & At school & No response \\
\hline Dlamvuzo & 13 & 1 & 0 & 3 & 4 & 6 \\
Dlangezwa & 3 & 2 & 1 & 0 & 0 & 26 \\
Dover & 4 & 2 & 4 & 0 & 0 & 2 \\
Empangeni & 20 & 1 & 1 & 0 & 0 & 11 \\
Hlamvana & 10 & 6 & 5 & 2 & 0 & 3 \\
Khula & 10 & 1 & 4 & 0 & 0 & 1 \\
Matamzana & 20 & 3 & 3 & 1 & 1 & 3 \\
Mdlamfe & 10 & 1 & 2 & 1 & 3 & 13 \\
Ongoye & 11 & 0 & 1 & 3 & 1 & 3 \\
RBH & 9 & 2 & 1 & 1 & 7 & 6 \\
RBS & 30 & 3 & 3 & 1 & 1 & 1 \\
St. Cath & 16 & 1 & 2 & 0 & 0 & 0 \\
Thanduyise & 6 & 0 & 0 & 0 & 2 & 13 \\
Tholokuhle & 2 & 0 & 3 & 0 & 0 & 11 \\
Tisand & 10 & 0 & 2 & 1 & 1 & 5 \\
\hline Total & 174 & 23 & 32 & 13 & 20 & 104 \\
\hline
\end{tabular}

Table 8 Time spent using ICTs per week $(\mathrm{N}=366)$

\begin{tabular}{|l|l|l|l|l|l|l|}
\hline School & None & $1-5$ hours & $6-10$ hours & II-15 hours & More than 16 hours & No response \\
\hline Dlamvuzo & 21 & 3 & 1 & 1 & 0 & 1 \\
Dlangezwa & 2 & 3 & 6 & 2 & 19 & 0 \\
Dover & 1 & 8 & 2 & 0 & 1 & 0 \\
Empangeni & 5 & 18 & 2 & 3 & 5 & 0 \\
Hlamvana & 11 & 8 & 3 & 0 & 1 & 3 \\
Khula & 1 & 10 & 2 & 0 & 3 & 0 \\
Matamzana & 15 & 8 & 5 & 2 & 1 & 0 \\
Mdlamfe & 17 & 11 & 0 & 0 & 0 & 2 \\
Ongoye & 10 & 4 & 3 & 1 & 1 & 0 \\
RBH & 0 & 22 & 4 & 0 & 0 & 0 \\
RBS & 12 & 20 & 4 & 0 & 2 & 1 \\
St. Cath & 0 & 15 & 2 & 0 & 2 & 0 \\
Thanduyise & 4 & 14 & 13 & 1 & 1 & 1 \\
Tholokuhle & 0 & 13 & 2 & 0 & 1 \\
Tisand & 6 & 10 & 1 & 0 & 0 & 2 \\
\hline Total & 105 & 167 & 37 & 10 & 36 & 11 \\
\hline
\end{tabular}


5.5 Time spent using ICTS

Most $(167 ; 46 \%)$ of the respondents use the ICTs for a maximum of I - 5 hours per week, while 36 (I0\%) spend considerably more time using the computers. As not many indicated that they used it for learning or specific academic purposes (such as writing assignments), it would be interesting to find out what activities are performed by those using ICTs, especially in a school like Dlangezwa, which appears to be very well equipped with a variety of ICTs. Table 8 shows the time spent by the respondents with ICTs.

5.6 Information seeking using ICTS

ICTs have had a profound influence on how individuals seek information. Moving away from having to just rely on paperbased sources, ICTs provide instant access to information sources worldwide. Seeking information using these sources is, however, not always straightforward and easily attainable. Table 9 indicates the respondents' abilities in terms of finding information using ICTs.

Table 9 Ability to find information using ICTs $(\mathrm{N}=366)$

\begin{tabular}{|l|l|l|l|l|l|}
\hline School & Always & Often & Sometimes & Never & No response \\
\hline Dlamvuzo & 5 & 0 & 9 & 13 & 0 \\
Dlangezwa & 13 & 10 & 5 & 4 & 0 \\
Dover & 5 & 2 & 5 & 0 & 0 \\
Empangeni & 10 & 9 & 7 & 1 & 6 \\
Hlamvana & 7 & 6 & 10 & 2 & 1 \\
Khula & 7 & 5 & 4 & 5 & 0 \\
Matamzana & 3 & 6 & 17 & 6 & 0 \\
Mdlamfe & 1 & 17 & 9 & 1 \\
Ongoye & 3 & 5 & 7 & 2 & 0 \\
RBH & 11 & 0 & 8 & 2 & 0 \\
RBS & 11 & 6 & 10 & 0 & 2 \\
St. Cath & 3 & 14 & 0 & 1 & 0 \\
Thanduyise & 5 & 16 & 6 & 1 & 0 \\
Tholokuhle & 2 & 9 & 9 & 5 & 1 \\
Tisand & 2 & 3 & 11 & 51 & 0 \\
\hline Total & 88 & 1 & 125 & 11 \\
\hline
\end{tabular}

It is encouraging to note that nearly half of the respondents (180;49\%) stated that they are skilled enough to find the information they need, either always or most of the time. Amongst the teachers the response rate was $65 \%$ indicating relatively high information retrieval skills rates amongst this group (Ntetha 2006). The high number of respondents who indicated that they find information only sometimes $(125 ; 34 \%)$ or never $(5 \mathrm{I} ; 14 \%)$ suggest the need for skills-training to enhance information seeking.

Table IO Rating computer skills $(\mathrm{N}=366)$

\begin{tabular}{|c|c|c|c|c|c|c|}
\hline Schools & Excellent & Very good & Good & $\begin{array}{l}\text { Enough to enable } \\
\text { me to work }\end{array}$ & None & No response \\
\hline Dlamvuzo & 1 & 0 & 2 & 2 & 12 & 10 \\
\hline Dlangezwa & 8 & 12 & 9 & 1 & 1 & 1 \\
\hline Dover & 0 & 3 & 7 & 2 & 0 & 0 \\
\hline Empangeni & 8 & 5 & 11 & 7 & 2 & 0 \\
\hline Hlamvana & 7 & 0 & 6 & 5 & 4 & 4 \\
\hline Khula & 3 & 8 & 4 & 1 & 0 & 0 \\
\hline Matamzana & 1 & 2 & 2 & 7 & 6 & 13 \\
\hline Mdlamfe & 1 & 2 & 5 & 5 & 2 & 15 \\
\hline Ongoye & 1 & 0 & 3 & 4 & 2 & 9 \\
\hline $\mathrm{RBH}$ & 14 & 2 & 5 & 4 & 1 & 0 \\
\hline RBS & 7 & 7 & 18 & 3 & 2 & 2 \\
\hline St. Cath & 1 & 7 & 8 & 2 & 1 & 0 \\
\hline Thanduyise & 3 & 5 & 9 & 4 & 0 & 0 \\
\hline Tholokuhle & 0 & 8 & 7 & 1 & 0 & 0 \\
\hline Tisand & 0 & 1 & 4 & 6 & 8 & 0 \\
\hline Total & 55 & 62 & 100 & 54 & 41 & 54 \\
\hline
\end{tabular}




\subsection{Computer skills}

The computer is arguably the most efficient ICT tool for information storage, retrieval, and dissemination within the education environment. Since computers can be used to do assignments, store class or extra notes for later retrieval, and retrieve information via the Internet or e-mail, the ability to operate the computer should be a skill expected of all learners. This question aimed to determine the level of computer training/skills the respondents had acquired. Table 10 indicates the results.

From the above, it appears that most respondents $(217 ; 59 \%)$ have enough skills to operate a computer with ease, while $54(15 \%)$ rated themselves as fairly able. As computers form the backbone of today's information economy, it is imperative that those learners who indicated that they do not have the necessary skills $(95 ; 30 \%)$ attain them before entering the workplace.

5.8 Utilisation of computers for information seeking and retrieval

The fact that an individual is computer literate does not necessarily mean that he/she can look for, and successfully retrieve information. Knowledge of data filing systems, useful keywords, and the construction of a search string, are all skills that determine the success or failure of information retrieval. Though it was mainly respondents from former Model C schools (state and parent supported schools) and private schools that indicated that they had information seeking and retrieval abilities using the Internet and e-mail, it was heartwarming to note that the more rural schools, such as Dlangezwa, Khula and Thanduyisa, also have access to these facilities, and that their respondents felt mostly confident about their ability to retrieve information. This is illustrated in Table II.

Table I I Computer searching skills $(\mathrm{N}=366)$

\begin{tabular}{|c|c|c|c|c|c|c|c|c|c|c|c|c|c|c|c|}
\hline Schools & Con & ters & & & & Inte & & & & & E-n & & & & \\
\hline & 1 & 2 & 3 & 4 & 5 & 1 & 2 & 3 & 4 & 5 & 1 & 2 & 3 & 4 & 5 \\
\hline Dlamvuzo & I & 0 & 3 & 2 & 21 & 1 & 0 & 1 & 0 & 25 & 0 & 0 & 1 & 0 & 26 \\
\hline Dlangezwa & 12 & 9 & 8 & 2 & 1 & 0 & 6 & 8 & 6 & 12 & 0 & 6 & 8 & 5 & 13 \\
\hline Dover & 1 & 2 & 7 & 2 & 0 & 0 & 0 & 3 & 1 & 8 & 0 & 0 & 4 & 1 & 7 \\
\hline Empangeni & 8 & 7 & 12 & 5 & 1 & 7 & 7 & 4 & 7 & 8 & 5 & 6 & 6 & 5 & 11 \\
\hline Hlamvana & 5 & 4 & 3 & 3 & 11 & 0 & 1 & 2 & 2 & 21 & 1 & 3 & 1 & 2 & 19 \\
\hline Khula & 7 & 7 & I & 1 & 0 & 5 & 1 & 8 & 2 & 0 & 5 & 1 & 2 & 3 & 5 \\
\hline Matamzana & 6 & 2 & 1 & 9 & 13 & 1 & 1 & 0 & 2 & 27 & 0 & 2 & 0 & 1 & 28 \\
\hline Mdlamfe & 0 & 1 & 6 & 9 & 14 & 0 & 0 & 3 & 4 & 23 & 1 & 2 & 1 & 1 & 25 \\
\hline Ongoye & 2 & 1 & 4 & 0 & 12 & 1 & 0 & 0 & 2 & 16 & 1 & 0 & 2 & 1 & 15 \\
\hline $\mathrm{RBH}$ & 15 & 0 & 8 & 1 & 2 & 13 & 2 & 1 & 8 & 2 & 14 & 3 & 4 & 2 & 3 \\
\hline RBS & 9 & 9 & 13 & 5 & 3 & 7 & 4 & 11 & 8 & 9 & 6 & 4 & 6 & 7 & 16 \\
\hline St. Cath & 4 & 7 & 6 & 1 & 1 & 6 & 7 & 5 & 0 & 1 & 6 & 7 & 2 & 0 & 4 \\
\hline Thanduyise & 4 & 3 & 8 & 4 & 2 & 4 & 3 & 3 & 7 & 4 & 1 & 3 & 7 & 3 & 7 \\
\hline Tholokuhle & 1 & 8 & 6 & 1 & 0 & 0 & 5 & 2 & 4 & 5 & 0 & 3 & 3 & 3 & 7 \\
\hline Tisand & 1 & 1 & 5 & 6 & 6 & 0 & 0 & 2 & 1 & 16 & 0 & 0 & 4 & 0 & 15 \\
\hline Total & 76 & 61 & 91 & 51 & 87 & 45 & 37 & 53 & 54 & 177 & 40 & 40 & 51 & 34 & 201 \\
\hline
\end{tabular}

$$
\begin{aligned}
& 1=\text { Excellent } \\
& 2=\text { Very good } \\
& 3=\text { Good } \\
& 4=\text { Enough to make me work } \\
& 5=\text { None }
\end{aligned}
$$

5.9 Internet utilisation: purpose and frequency

From an educational point of view, the Internet can be used to find information contained on web pages, allows e-mail communication, discussion groups, and the downloading of software. The respondents were required to indicate which of these activities they most frequently perform when using the Internet. Their responses are shown in Table 12. 
Table 12 Frequency of using Internet services

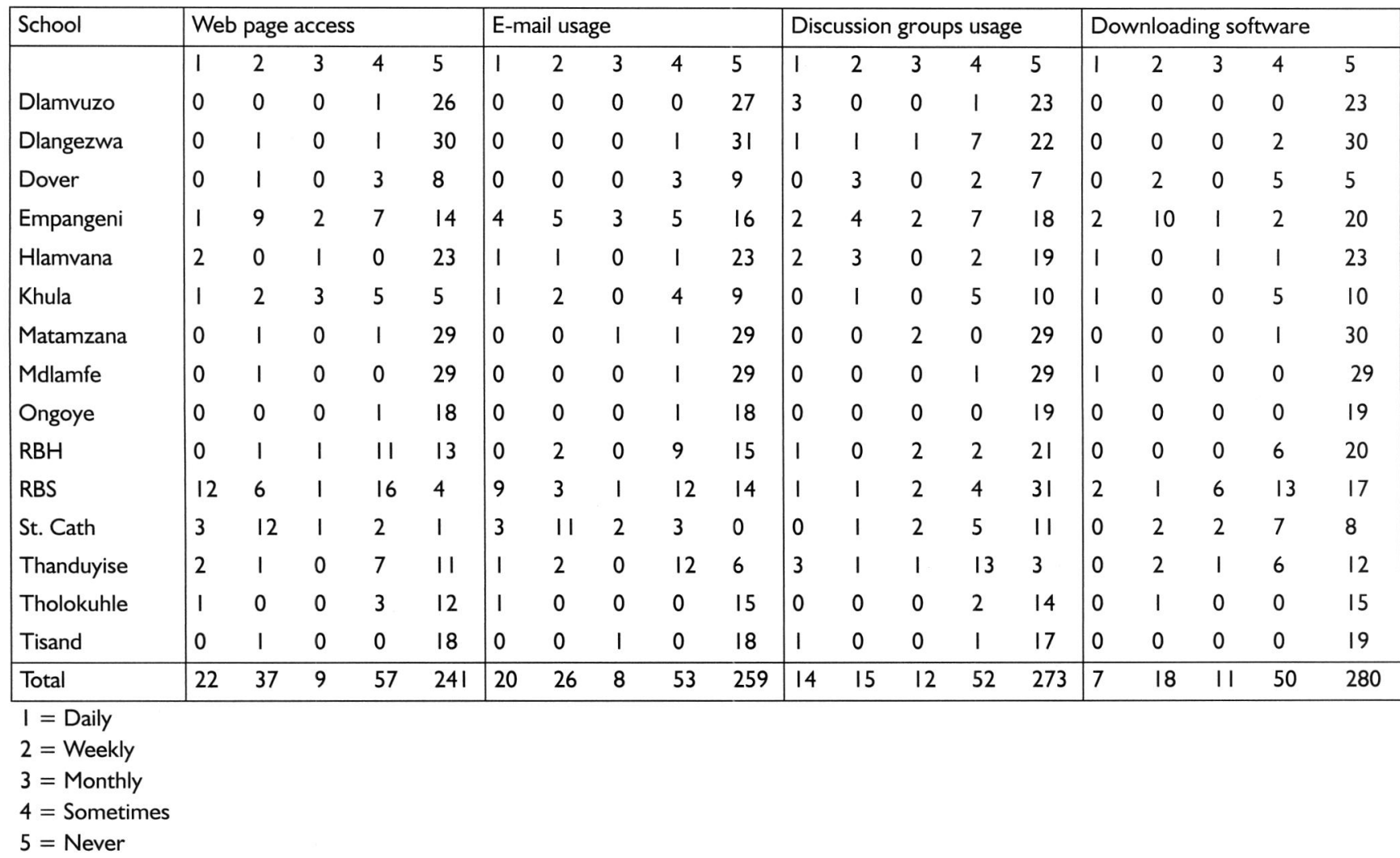

Although the questionnaire stated clearly that answers should concern only the utilisation of ICTs within the school environment, it is clear that some learners also included home searching, as evidenced by the difference in the responses of Tables 5 and 12. However, Table 12 is still a positive indication that although not always available at school, technology is accessed and used at other venues.

As expected, web pages $(125 ; 34 \%)$ were cited as the most common reason for using the Internet. Because the reasons for visiting these pages were not stated by the respondents, it is assumed that the visits relate to school work and finding information that they needed to cope with everyday life (e.g. information on careers, health information, the daily news, or for accessing music files or games). Visits were mostly of an infrequent nature, possibly because of restricted access or a lack of funds on the part of the school. The second most utilised service was communication (106; 29\%). This correlates with the high number of respondents who indicated that they use ICTs for communication purposes, as shown in Table 6. The same pattern was detected amongst the teachers (Nthetha 2006). In turn, these findings correspond with those of Isaacs (2002), who found that access to the Internet and the communication abilities that it affords learners had a positive effect on the learning environment for both learners and teachers.

5.10 Communication patterns

Technology has changed the way in which humans communicate. To verify this, the respondents were asked whether ICTs have changed their patterns of communication. Most of the respondents $(216 ; 60 \%)$ indicated that they had, and $150(40 \%)$ responded negatively or did not respond to the question. Table 13 shows the results.

The positive response could mean that most of today's learners are engaging more and more with technology, which enables them to function and behave in a way that was unthinkable in the past. The relatively high negative response shows that many learners are still excluded from technologies that could enhance their learning and communication experience. 
Table 13 ICTs changing communication $(\mathrm{N}=366)$

\begin{tabular}{|l|l|l|l|}
\hline School & Yes & No & No response \\
\hline Dlamvuzo & 11 & 16 & 0 \\
Dlangezwa & 24 & 6 & 2 \\
Dover & 9 & 3 & 0 \\
Empangeni & 16 & 15 & 2 \\
Hlamvana & 20 & 6 & 0 \\
Khula & 13 & 3 & 0 \\
Matamzana & 19 & 12 & 0 \\
Mdlamfe & 1 & 29 & 0 \\
Ongoye & 8 & 11 & 0 \\
RBH & 18 & 6 & 2 \\
RBS & 31 & 6 & 2 \\
St. Cath & 15 & 4 & 0 \\
Thanduyise & 13 & 7 & 1 \\
Tholokuhle & 12 & 4 & 0 \\
Tisand & 6 & 13 & 0 \\
\hline Total & 216 & 141 & 9 \\
\hline
\end{tabular}

The respondents were also asked to indicate how they think ICTs have changed their communication patterns. The following answers were received and are directly quoted:

Dlangezwa: $\quad-$ ICTs have made accessing information very easy and cheap. Some years back, it could take 3 months to communicate with somebody abroad, but now it can take seconds via e-mail to talk to someone abroad.

Dover: $\quad$ - The fax machine receives information very fast.

- Information can now be accessed using Television, Radio, Phones, Video, etc.

- There are a lot of resources to obtain information from. ICTs have indeed changed the way of communicating/receiving information.

Empangeni: $\quad$ - ICTs are much quicker. ICTs bring about independence because computers only need one operator.

- Educated people hardly talk face to face these days; they use fax and e-mailing services to talk.

- Internet is easy and fast to use and downloads offer a lot of information. ICTs have changed my skills, especially my computer skills.

Hlamvana: $\quad$ - ICTs help to gain more knowledge.

- Tools like computers (Internet) help you download a lot of information.

- With ICTs, communication is very easy.

Khula: $\quad$ - These days, e-mails are used for communication purposes - which was not the case some years ago.

- Computers store everything that is documented these days.

- There is not much need for using libraries because computers (Internet) have everything a user may need.

Matamzana: - Faxing is really helping in speeding up the receiving of information.

Mdlamfe:

- ICTs have changed the way learners communicate educational information because ICTs provide updated information every time.

Ongoye: $\quad$ - Although learners are not using ICTs, these tools make communication very easy for educational purposes.

Richards Baai - ICTs make communication so easy, like when phoning using a mobile phone you can talk with Hoërskool: someone from another place without physically seeing that person.

- By learning how to use a computer, I have changed the way I receive educational information. 
Richards

Secondary:

St. Cath

Thanduyise:

Tholukhule

Bay - ICTs are much quicker and more convenient for learners to use.

- The Internet has a lot of information. ICTs brought about many ways to communicate, e.g. cell phones, telephones, e-mails, etc.

- ICTs are very specific and accurate.

- ICTs have speed. With e-mails the world can communicate in seconds

- By using the Internet, a lot of information can be obtained.

- Mobile phones are anytime, anywhere, and they are easy and cheap to use.

- I can retrieve important messages related to school using the fax machine.

- Because I know how to communicate with other people and receive from others.

- I now sometimes use other services other that the usual ones.

- I can now go to the computer and send information and receive information from it.

- I don't have to wait for a response from my relatives, I just phone and get answers immediately.

- If we want information from other schools we use some of the ICTs.

Many of the respondents commented on the ease and speed with which one can obtain information that is necessary, and also on the fact that a vast pool of information is available through the use of ICTs. With the paucity of libraries available in schools, ICTs have the potential to fill in the gap and act as catalysts in information provision and the extension of extracurricular material, or information supplementing class notes and textbooks.

5.11 Altered information seeking patterns

Traditionally, learners were required to find additional educational information by means of the printed media, be it in the school library, public library, sources at home, or from newspapers. With the availability of ICTs, information seeking and retrieval patterns have been drastically altered. As the global economy requires this adaptation, it is encouraging to note that nearly half $(181 ; 49 \%)$ of all the respondents indicated that they have already changed how they seek and retrieve information. Once again, the schools with the most ICTs available had the highest positive responses, e.g. Dlangezwa, Empangeni High School, Richards Bay Secondary School and St. Catherine's. Table 14 shows the results.

Table 14 Altered information seeking and retrieval patterns $(N=366)$

\begin{tabular}{|l|l|l|}
\hline School & Yes & No \\
\hline Dlamvuzo & 10 & 17 \\
Dlangezwa & 21 & 11 \\
Dover & 7 & 5 \\
Empangeni & 18 & 15 \\
Hlamvana & 14 & 12 \\
Khula & 12 & 4 \\
Matamzana & 12 & 19 \\
Mdlamfe & 1 & 29 \\
Ongoye & 9 & 10 \\
RBH & 13 & 13 \\
RBS & 29 & 10 \\
St. Cath & 16 & 3 \\
Thanduyise & 11 & 10 \\
Tholokuhle & 4 & 12 \\
Tisand & 4 & 15 \\
\hline Total & 181 & 185 \\
\hline
\end{tabular}

The respondents were asked to identify how their information seeking and retrieval patterns differed from before. The following answers were received:

Dlangezwa: $\quad$ - With the introduction of ICTs, there is absolutely no need to visit libraries for information, but instead computers, TV, radio, and phones can be used to get information very quickly and easily.

Dover: - All information needs are solved through the Internet, instead of wasting more hours in the library. 
Empangeni: - Getting information is easy and fast. The user just clicks and the information is there.

- Computers and CD-ROMs are effective.

- No library use at all is necessary.

Hlamvana:

- Seeking information using ICTs is much easier; for instance, on the Internet the user just types the instructions and the computer retrieves information in no time.

Matamzana:

- Information can now be downloaded in large volumes from the Internet.

Mdlamfe:

- ICT tools have changed the way of seeking information because learners don't need to go to the library in search of information; they just sit next to the computer and download information.

Ongoye:

Richards

Hoërskool:

- ICTs have replaced the traditional way of looking for information from the library by searching through the Internet.

Richards

Secondary:

Baai - By using computers to download information instead of a library, ICT tools are very fast in giving information.

Bay - ICTs are much quicker and convenient for learners to use.

- The Internet has a lot of information.

- ICTs brought about many ways to communicate, e.g. cell phones, telephones, e-mails, etc.

St. Catherines: - You can hardly get information from the library, but using ICTs, especially the Internet, a lot of information can be obtained.

Thanduyise:

- Libraries may have limited sources, but with the Internet everything can be found very easy and cheap.

Although the learners noted the ability to find information quickly on the Internet, the fact that so many felt that the downloading aspect was a big asset is a worrying issue, since the question of plagiarism has to be addressed. If teachers do not inform their learners about the dangers of copying and pasting information, they might assume that it is an allowed practice. This could lead to significant problems on tertiary level.

The fact that the Internet is seen as a much more useful and readily accessible source than the library should also ring warning bells to educators. While a lot of information on the Internet is authoritative and objective, a fair amount isn't, and should the learner not be able to distinguish between the two, they might supplement their education with false information. It is therefore imperative that qualified teachers be part of the skills-training process during information seeking and retrieval.

\subsection{Limitations affecting ICT utilisation}

With the development of proper ICT infrastructure still in its infancy, it can be assumed that there would be problems hampering ICT utilisation. Respondents were asked what they perceived as problems or limitations, and Table 15 indicates their responses.

Table 15 Limitations affecting ICT usage $(\mathrm{N}=366)$

\begin{tabular}{|c|c|c|c|c|c|c|c|c|}
\hline School & $\begin{array}{l}\text { No } \\
\text { electricity }\end{array}$ & $\begin{array}{l}\text { No telephone } \\
\text { lines }\end{array}$ & $\begin{array}{l}\text { No mobile } \\
\text { phones }\end{array}$ & $\begin{array}{l}\text { No safe } \\
\text { rooms }\end{array}$ & No security & $\begin{array}{l}\text { Untrained learners } \\
\text { and staff }\end{array}$ & No radio & No Video \\
\hline Dlamvuzo & $x$ & - & $x$ & $x$ & $x$ & - & - & - \\
\hline Dlangezwa & $x$ & - & - & - & - & - & - & - \\
\hline Dover & $x$ & - & $x$ & $x$ & - & $x$ & $x$ & - \\
\hline Empangeni & $x$ & - & $x$ & $x$ & $x$ & $x$ & - & - \\
\hline Hlamvana & $x$ & - & $x$ & $x$ & - & $x$ & - & - \\
\hline Khula & - & - & $x$ & $x$ & - & $x$ & - & - \\
\hline Matamzana & $x$ & $x$ & $x$ & $x$ & $x$ & $x$ & $x$ & - \\
\hline Mdlamfe & $x$ & - & $x$ & $x$ & $x$ & - & - & - \\
\hline Ongoye & $x$ & $x$ & $x$ & $x$ & - & $x$ & - & - \\
\hline RBH & $x$ & - & $x$ & - & $x$ & $x$ & - & - \\
\hline RBS & $x$ & - & $x$ & $x$ & $x$ & $x$ & - & - \\
\hline St. Cath & $x$ & - & $x$ & $x$ & - & $x$ & - & - \\
\hline Thanduyise & $x$ & - & - & - & - & - & - & - \\
\hline Tholokuhle & $x$ & - & $x$ & - & - & $x$ & - & - \\
\hline Tisand & $x$ & - & $x$ & - & $x$ & $x$ & - & $x$ \\
\hline
\end{tabular}


There are several limitations mentioned in the use of ICTs amongst the participating schools, the most notable problem being the lack of electricity. Interestingly, even schools that are known to have electricity available had respondents citing it as a problem. It is, of course, possible that electricity was not working or not available in certain classrooms or to operate an ICT that they would have liked to use, such as a computer. The lack of trained teachers (33; 9\%) who could assist learners with the acquisition of ICT skills, was cited as another major problem. The study by Ntetha (2006) showed that inadequately trained teachers was perceived as a more serious problem amongst the staff themselves, as $8(18 \%)$ thought it was a problem. The overall small number amongst both staff and learners perceiving it as a problem, indicates a lack of insight amongst most staff and learners as to the seriousness thereof. Many of the teachers currently in the school system have never had ICT training (particularly computers and the Internet), and are therefore unable to provide assistance. This problem is common, as noted in the studies done by Govender and Maharaj (n.d.), the Education Policy Unit of the University of the Western Cape, and the International Development Research Centre (2000).

\section{Conclusions}

Although many of the schools are relatively well-equipped as far as ICTs are concerned, access seems to be the biggest stumbling block. Observed that if the Department of Education is serious about exposing all learners to ICTs by 2013 , accessibility needs to be addressed. This would have considerable implications on schools, for instance extra staff might be hired to support computer labs on a permanent basis, and/or also after school. Alternatively, the existing staff would have to bear the brunt and take on even more responsibilities, despite already being overworked. Visibly, learners assistants from Grade 12, who would oversee computer labs or operate fax machines, televisions, or video machines could be trained to support the system. In this way, the learners would gain valuable work experience, and the teachers would be free to carry on with their normal work.

The cost of implementing and maintaining ICTs, especially computers, the Internet, and electronic databases, can place huge financial strain on most schools' budgets, especially since technology ages rapidly and needs to be upgraded or replaced often. Commitment from the government in the form of an ICT subsidy could alleviate some of these problems, but whether this would make much of a difference in the poorest schools is debatable. Other pressing needs might result in the funds being committed elsewhere.

Despite the general lack of access to ICTs at schools, it would appear that the learners were quite informed as to the advantages of using ICTs for knowledge acquisition and communication. Although they lamented the lack of skills and opportunities available at school to learn to use ICTs, especially computers, many have already managed to master some of the skills necessary to use them for a variety of purposes. These abilities need to be enhanced and fostered, and where possible, applied, in order to prepare the learners for the working environment and enable life-long learning. Most employment opportunities are linked to the knowledge and utilisation of ICTs. The matter therefore needs the school authorities' most considerate attention if all schools are to be equipped with the tools and trained teachers necessary to instill these skills in all learners. Only when each learner exits the school environment as an ICT literate individual, can schools judge themselves to some extent as having succeeded in preparing them for the global environment. Herselman (2002) suggested that a possible solution to overcoming the lack of ICT access could be through the use of mobile phones that provide access to the Internet.

If the low number of learners (5\%) indicating that they obtained their ICT skills from school, is an indication of the number of learners enrolled for Computer Studies, it is a source of concern, as the country is currently experiencing serious skills shortages; knowledge of computers and programming being one of the areas where a need is experienced. As these learners are taught valuable practical skills that can be directly applied in the work environment, attendance of this study area should be promoted in schools with the necessary capacity to do so.

The fact that communication is still the most prominent reason for ICTs' use, both among staff and learners, shows that information seeking and retrieval skills - using tools like the Internet and databases to actually find and retrieve information - are still lacking. Alarming is the fact that neither staff not learners use ICTs for class preparation, finding additional information, or in the case of the learners, for assignment writing. Since a wealth of information is available to supplement teaching and learning through the use of ICTs this is shortcoming needs to be addressed because the global world expects individuals to be able to retrieve and use information for problem solving. Failing to do so can lead to failure in the work and social environment. As the learners, and staff, indicated considerable time spent using the ICTs, seemingly mainly for communication purposes, education in, and promotion of, the other functionalities of ICTs, such as information searching and retrieval for academic purposes, should be seriously considered.

Teachers and the educational departments should take note of the altered communication and information seeking patterns amongst learners that emerged from the study. Young adults worldwide display a preference to communicate and learn through technology-supported media rather than just print-base and therefore technologies such as mobile 
phones and computers should be used where possible to encourage computer skills development, and information access and utilisation.

A daunting challenge is the fact that many of the teachers currently in the profession are not computer literate, thus not only hampering their own efforts to retrieve and utilise this important information resource for teaching purposes, but also prohibiting them from assisting or teaching the learners in using it effectively. Often when the teacher is not computer literate, the learners are also barred from using the available computers, thus rendering them useless educational tools. Teacher education and training courses should thus take this shortcoming into account and hone the necessary skills either during the teachers' training years, or through short courses and hands-on workshops.

To reach the 2013 goal, government will have to be actively involved in various aspects concerning the introduction and exposure of ICTs to all learners. Not only should they provide clear policy guidelines as to what ICTs the learners should be introduced to, but also how schools will be equipped with the ICTs, especially schools that lack the most basic infrastructure, such as electricity, strong rooms, and qualified teachers. Government can not expect the school community to supply the entire costly infrastructure, and therefore assistance should come in the form of subsidies, extra budgets specifically for ICTs, and budgeting for the training of the teaching staff.

Though the utilisation of ICTs has become the norm in many developed countries, developing countries like South Africa still have a long way to go before they can afford all their learners equal chances to compete in the technological and information environment in which they will live and work.

\section{References}

Babliobrezeske, M \& Cohen, S. 2003. Managing ICTs in South African Schools: A guide for principals. [Online]: http:// www.saide.org.za/resources/0000000108/Final_Saide_Layout(Screen).pdf. Accessed 24 March 2007.

De Jager, A.K. and Lockman, A.H. .I999.. Impacts of ICT in education. The role of the teacher and teacher training. [Online]: http:/ /www.leeds.ac.uk/educol/documents/00001201.htm. Accessed 22 March 2007.

Department of Education. 2004. Draft white paper on education: transforming education and learning through information and communication technologies (ICTs). Government Gazette, 470:26734:I-44. [Online]: http://www.info.gov.za/gazette/ whitepaper/2004/26734.pdf. Accessed 26 March 2007.

Education Policy Unit of the University of the Western Cape and the International Development Research Centre. 2000. Computers in Schools: A national survey of Information Communication Technology in South African schools [Online]: http:/ /www.school.za/schoolsurveys/suveys_index.htm. Accessed 18 September 2007.

Govender, D.W. and Maharaj, M. (n.d.). Challenges with Respect to the e-Readiness of Secondary School Teachers in KwaZuluNatal, South [Online]: Africa http://delivery.acm.org//0.//45//270000//26884//p/9/govender.pdf?key $I=|26884| \&$ key $2=79885798|| \&$ coll $=\& d|=A C M \& C F I D=| 5|5| 5 \mid 5 \& C F T O K E N=6 / 846 / 8$. Accessed $\mid 4$ September 2007.

Haddad, W. D \& Jurich, S. 2002. ICT for education: potential and potency. [Online]: www.iastate.edu/ ilet/reading_groups/readingsoct03.html. Accessed 8 May 2007.

Herselman, M.E. 2002. ICT bridging the digital divide amongst learners: A case study in South Africa. [Online]: htrtp:// www.asclite.org.au/aset-archives/confs/2002/herselman.thml. Accessed 12 September 2007.

Herselman, M.E. 2003. ICT in rural areas in South Africa: Various case studies. [Online]: http://www/informingscience.org/ proceedings/IS2003Proceedings/docs/ I 20Herse.pdf. Accessed 17 September 2007.

Holcroft, E. 2004. SchoolNet South Africa, in James, T. ed. 2004. Information and communication technologies for development in Africa: volume3: Networking Institutions of Learning - SchoolNet. [Online]: http://www.idrc.ca/en/ev-33006-20I-IDO_TOPIC.html. Accessed 8 May 2007.

Intel World Ahead Program: case studies. (n.d.). [Online]: http://www.intel.com/intel/worldahead/casestudies_africal.html. Accessed 27 July 2007.

Isaacs, S. 2002. ICTs in African schools: a multimedia approach for enhancing learning and training. TechKnowLogia, January March. [Online]: http://www.schoolnetafrica.net/fileadmin/resources/techknowlogia2002africa.pdf. Accessed 17 September 2007.

Isaacs, S., Broekman, I \& Mogale, T. 2004. Contextualising Education in Africa: The Role of ICTs in James, T. ed. 2004. Information and communication technologies for development in Africa: volume3: Networking Institutions of Learning - SchoolNet. [Online]: http://www.idrc.ca/en/ev-33006-20I-I-DO_TOPIC.html. Accessed 8 May 2007.

Isaacs-Bardien, S. 2004. Towards a strategy on developing African teacher capabilities in the use of information and communication technologies. [Online]: http://www.col.org/colweb/webdav/site/myjahiasite/shared/docs/04Towards_Strategy_Africa.pdf. Accessed 8 May 2007.

James, T. ed. 200I. Information policy handbook for Southern Africa. [Online]: http://network.idrc.ca/en/ev-I/538-20I-IDO_TOPIC.html. Accessed I7 September 2007.

James, T. ed. 2004. Information and communication technologies for development in Africa: volume3: Networking Institutions of Learning - SchoolNet. [Online]: http://www.idrc.ca/en/ev-33006-20I-I-DO_TOPIC.html. Accessed 8 May 2007.

National survey on ICT education in South African schools. (n.d) [Online]: http://www.idrc.ca/es/ev-83066-20I_003998-IIDRC_ADM_INFO.html. Accessed I2 September 2007.

Ntetha, M.A. 2006. The utilization of ICTs by staff and learners of High Schools in Umhlatuze City. (Unpublished report). KwaDlangezwa: University of Zululand. 
Roithmayr, D 2002. The Constitutionality of School Fees in Public Education. [Online]: http://www.erp.org.za/htm/issue /-2.htm. Accessed 27 August 2007.

Rusten, E. n.d. Using computers in Schools. [Online]: http://learnlink.aed.org/Publications/Sourcebook/chapter4/ Computers_in_Schools_modelofuse.pdf. Accessed 7 May 2007.

Sarantakos, S. 1997. Social research. $2^{\text {nd }}$ ed. Hampshire: Palgrave.

Umhlatuze City Annual report 2005/06. 2006. [Online]: http://www.richemp.org.za/TulipuMhlathuzelnternet/repository/ uMhlathuze\%20News/Annual\%20Report/annual_report_06.pdf. Accessed 23 May 2007. 